\title{
Effects of Mulch Material and Mulching Rate on Fruit Yield and Nutritional Quality of Tomato Variety (Lycopersicon lycopersicum mill) in Ogbomoso and Mokwa, Nigeria
}

\author{
Tswanya $\mathrm{MN}^{1 *}$, Olaniyi $\mathrm{JO}^{2}$ and Atanda $\mathrm{TT}^{2}$ \\ ${ }^{1}$ Department of Biotechnology Advanced Research Centre, Sheda Science and Technology Complex, Nigeria \\ ${ }^{2}$ Department of Agronomy, Ladoke Akintola University of Technology, Nigeria
}

Submission: May 16, 2017; Published: June 16, 2017

"Corresponding author: Tswanya MN, Department of Biotechnology Advanced Research Centre, Sheda Science and Technology Complex, Garki-Abuja, Nigeria, Email: ndamayakimatthew@gmail.com

Abstract

Field experiment was conducted at the teaching and Research Farm, Ladoke Akintola University of Technology, Ogbomoso and Niger State College of Agriculture, Mokwa, in 2014 cropping season to examine the effects of mulch materials and mulching rates on fruit yield and nutritional qualities of tomato variety. The experiment had fifteen treatments viz: three mulch materials (rice husk, groundnut shell and dry guinea grass) and five mulching rates $\left(0,5,10,15\right.$ and 20 in tha $\left.^{-1}\right)$, replicated three times. The experiment was laid out as split plot arranged in Randomized Complete Block Design. Data were collected on plant height, number of flowers, number of fruits and total fruit yield.

The determination of fruit phytochemical contents at full ripening, 6 fruit samples were randomly selected per plot and analysed for nutritional qualities such as crude Protein, Carotene, Iron, Phosphorus, Potassium, Calcium, Lycopene, Magnesium, Vitamin C contents. Data was analysed using analysis of variance (ANOVA) SAS package and treatment means compared using least significant difference (LSD) at 5\% probability level. Mulching is beneficial to performance of tomato. Mulch types had no effect on fruit yield of tomato. Plants mulched with 15 tha ${ }^{-1}$ produced the highest yield $\left(23.30\right.$ tha $\left.^{-1}\right)$ while control plots had the least value (8.13 tha ${ }^{-1}$ ). Nutritional qualities (Lycopene, phosphorus, potassium) were best at mulching rate of $15 \mathrm{t} \mathrm{ha}^{-1}$. It could be concluded that mulching is beneficial to tomato production; mulch rate of 15 tha ${ }^{-1}$ performed better than other rates evaluated and could be recommended for the farmers within the study areas.

Keywords: Tomato; Mulching material; Mulching rate; Nutritional quality

\section{Introduction}

Tomato (Lycopersicon lycopersicum) belongs to the solanaceae family. It originated in Peru and Mexico, in the present day Central and South America from where it spread to other parts of the world [1]. Tomato reached Europe from Mexico in the $16^{\text {th }}$ century, and was initially used as ornamental plant. Its cultivation for edible fruits started at the end of the $18^{\text {th }}$ century. Tomato was introduced to West Africa and Nigeria in particular, at the end of the $19^{\text {th }}$ century [2]. It is currently considered to be one of the main vegetable crops in the world, and constitutes an economic force that influences the income of many growers in the world [3]. In Nigeria tomato also finds its way into almost every kitchen. Tomato crop is very important in terms of diet and economy in Nigeria both during the rainy season (rainfed) and dry season using irrigation facilities. It is used as a condiment in stews and soup or eaten raw in salads. Industrially, the crop is made into puree, sauce, paste and powder [4].

Mulching is the process or practice of covering the soil/ ground to make more favourable conditions for plant growth, development and efficient crop production. Mulch technical term means 'covering of soil' [5]. While natural mulches such as leaf, straw, dead leaves and compost have been used for centuries, during the last 60 years the advent of synthetic materials has altered the methods and benefits of mulching. When compared to other mulches plastic mulches are completely impermeable to water; it therefore prevents direct evaporation of moisture from the soil and thus limits the water losses and soil erosion over the surface [6]. In this manner it plays a positive role in water conservation and the suppression of evaporation also has 
a supplementary effect; it prevents the rise of water containing salt, which is important in countries with high salt content water resources [7].

Mulching is a layer of material on the surface of the soil used to keep soil moist or to serve a wide variety of other purposes. Organic mulches are those derived from the dead plant and animal tissues, which apart from soil protection also serve as nutrient sources when they decay. Tomato plants subjected to mulching and fertilization exhibited the highest plant height when compared with the other treatment combinations [8]. Mulching has been identified by many researchers as a method to provide a favourable soil environment by minimizing crusting at the soil surface and keep it stable [9]. Influence of mulching on tomato production has been reported by many researchers [10]. This practice increases the infiltration of rain water and suppress the growth of weeds. Mulching is effective in reducing evaporation, conserving soil moisture and has been known to modify the hydrothermal regime of soil [11].

Mulching of tomato plants with Tithonia diversifolia leaves and fertilizer application together promoted growth and development i.e. number of nodes, number of leaves and height, as well as fruit production i.e. number of fruits, number of seeds per fruit, fruit size, fruit shape and duration of fruiting activity. In the experiment conducted by [9], three tomato varieties namely, Ratan, BARI tomato- 3 and BARI tomato- 6 were experimentally evaluated to identify the potential mulch on growth and yield, where the experiment consisted of four mulching treatments: water hyacinth, straw, am-ada leaf and banana leaf with a control (no mulch). The experiment was conducted under rain fed condition. The result showed that mulching significantly had effect on growth, yield components and thus on the yield of tomato. Mulching is effective in reducing evaporation, conserving soil moisture and has been known to modify the hydrothermal regime of soil [11]. The bad effects of water deficit could be overcome by irrigation or adopting insitu moisture conservation techniques, such as use of mulches [12]. Mulches are effective in reducing soil moisture loss from evaporation. Organic mulches are effective, but when moisture is applied by irrigation or through rainfall, the amount should be adequate to reach the soil. Organic mulches tend to settle with time. Some are less resistant and decompose after a short time. As such, it may be necessary to add fresh material to the original layer to make it effective in retaining moisture [13]. The agronomic characteristics of tomato as influenced by irrigation and mulching were examined. Mulching and no mulching were evaluated. Rice straw was used as mulching material at the rate of $5 t / h$. The mulching significantly affected the fruit yield in such a way that mulched plots produced about two times more fruit yield than those without mulch [14]. The effects of $L$. leucocephala and G. Sepium mulches (and their mixtures) on the growth and yield of okra was assessed.
The mulches were applied at the rate of 0,5 and 10 tha- 1 . The mulches did not significantly improve the chemical properties of the soil, but improved the growth rate and yield of okra. Generally, the higher the amount of mulch applied, the better the growth and yield of okra [15]. Mulching, using any of the materials like green leaves, dried leaves and coconut fronds significantly increased tomato fruit yield by $65.30 \%$ over the control and they attributed the increase to the slight improvement in the physical properties of soil [16]. Similarly, mulches applied at very low rates e.g. 2.5 tha- 1 or 5 tha $^{-1}$ can significantly increase growth and yields of highly valuable vegetable and fruits crops in the field [17].

Trash farming suppresses weed germination and retard growth and development of many weeds, reduces soil erosion and conserves soil moisture. In the low and intermediate rainfall areas, tomato is mulched with trash [18]. This helps in conservation of soil moisture and fertility [19]. Trash placed on the soil surface losses $55-60 \%$ of its organic matter after 270 days compared with $70-75 \%$ when it is incorporated in the soil [20]. Use of clear polythene and plastic present the potential advantage of soil solarisation [21]. Application of organic materials such as dried papaya leaves could also make the plants grow fast and retard the growth of weeds around the plants. These organic materials which are added to the soil are collectively termed as organic mulch. Others organic mulches include grass clippings bark, sawdust and manure, hay, straw, shells, wood chips, shredded newspaper, cardboard and wool [22]. Despite many investigations in the area of nutrition, knowledge on how mulching material and mulching rates influences physical and phytochemical contents of tomato fruit is insufficient. This study determined plant growth, fruit yield and nutritional qualities of tomato variety in Ogbomoso and Mokwa, Nigeria as influenced by mulch material and mulching rates.

\section{Materials and Methods}

The experiment was conducted at two locations; Teaching and Research Farm, Ladoke Akintola University of Technology, Ogbomoso $\left(8^{\circ} 10^{1} \mathrm{~N} ; 4^{\circ} 10^{1} \mathrm{E}\right)$ and Niger State College of Agriculture, Mokwa ( $9^{\circ} 18^{1} \mathrm{~N}$ and $\left.5^{\circ} 04^{1} \mathrm{E}\right)$, during 2014 cropping season. The experimental plot was ploughed and harrowed after which lining out was carried out. There were 45 plots with three replications. Each replicate consisted of 15 plots. Each treatment was in a bed plot size of $2.5 \mathrm{mx} 2.0 \mathrm{~m}\left(5.00 \mathrm{~m}^{2}\right)$. A plot contained 25 plants. The total experimental area was $405.00 \mathrm{~m}^{2}\left(0.041 \mathrm{ha}^{-1}\right)$. The alley way between replicates was $1.0 \mathrm{~m}$ and within replicates was $1.0 \mathrm{~m}$ with inter and intra-row spacing of $50 \mathrm{~cm} \times 50 \mathrm{~cm}$. Three mulch materials that were used included: Rice husk, Groundnut shell and Dry guinea grass while the mulching rates involved: $0,5,10,15$ and 20 tha $^{-1}$. The test crop used was UC82B tomato variety. The treatment was laid out as split plot arranged in Randomized Complete Block Design, replicated three times. 
The seeds were sourced from the Department of Crop Production and Soil Science, Ladoke Akintola University of Technology, Ogbomoso and from the Department of Agricultural Technology, Niger State College of Agriculture, Mokwa. The tomato seeds were sown on nursery beds containing pulverized soil and the seedlings were raised for four weeks before transplanting to the field at the two locations. Watering in the nursery was done as at when needed. Healthy and vigorous seedlings were transplanted into the field in order to ensure uniformity. Watering was done using watering-can to supplement rainfall. Pesticide in form of cypermethrin was applied at the dosage of $25 \mathrm{ml}$ per 15 litres of knapsack sprayer fortnightly to check caterpillars, worms and grasshoppers.

Manual weeding was also carried out using hoe at three weeks interval starting from 2 WAT to reduce competition between weeds and plants. Data were collected on plant height, number of flowers, number of fruits and total fruit yield. The determination of fruit phytochemical contents at full ripening, 6 fruit samples were randomly selected per plot and analysed for nutritional qualities such as crude Protein, Carotene, Iron, Phosphorus, Potassium, Calcium, Lycopene, Magnesium, Vitamin C contents. In order to assess these, 6 fruit samples were collected and dried in an oven at $85{ }^{\circ} \mathrm{C}$ for 72 hours. The dried fruit samples were separately ground with a Wiley mill, and passed through a $0.5 \mathrm{~mm}$ sieve for tissue analysis. Total $\mathrm{P}$ was determined by the Vanadomolybdate method, $\mathrm{K}$ and $\mathrm{Ca}$ was determined by the flame photometry and $\mathrm{Mg}$ and Fe were determined by atomic absorption spectrophotometer [23]. Total $\mathrm{N}$ was analyzed by the micro-Kjeldahl procedure as described by IITA [23] and crude protein was obtained by multiplying the total $\mathrm{N}$ by a factor of 6.25. Data collected were subjected to Analysis of Variance (ANOVA) using SAS statistical package. Treatment means were separated using the least significant difference (LSD) at 5\% probability level.

\section{Plant Height (cm)}

Table 1: Effect of mulch material and mulching rate on plant height of tomato plants in 2014 cropping season.

\begin{tabular}{|c|c|c|c|c|c|c|}
\hline \multirow{3}{*}{ Mulch Material } & \multicolumn{6}{|c|}{ Plant Height (cm) } \\
\hline & \multicolumn{6}{|c|}{ Mulching Rate ( $\mathrm{t} \mathrm{ha}{ }^{-1}$ ) } \\
\hline & 0 & 5 & 10 & 15 & 20 & MM Mean \\
\hline \multicolumn{7}{|c|}{ 2WAT } \\
\hline RH & 18.9 & 20.4 & 25.7 & 23.3 & 23.6 & 22.4 \\
\hline GS & 20.7 & 22.4 & 21.9 & 26.3 & 21.0 & 22.5 \\
\hline DG & 24.4 & 20.1 & 24.0 & 26.7 & 20.8 & 23.2 \\
\hline MR Mean & 21.3 & 21.0 & 23.9 & 25.4 & 21.8 & \\
\hline LSD (0.05) MM & ns & & & & & \\
\hline MR & 2.89 & & & & & \\
\hline MM x MR & ns & & & & & \\
\hline \multicolumn{7}{|c|}{ 4WAT } \\
\hline $\mathrm{RH}$ & 30.9 & 28.7 & 39.2 & 39.7 & 39.9 & 35.7 \\
\hline GS & 29.2 & 34.9 & 31.7 & 40.9 & 31.0 & 33.5 \\
\hline DG & 31.3 & 30.4 & 35.8 & 39.0 & 34.5 & 34.2 \\
\hline MR Mean & 30.5 & 31.3 & 35.6 & 39.9 & 35.1 & \\
\hline LSD (0.05) MM & ns & & & & & \\
\hline MR & 3.65 & & & & & \\
\hline MM x MR & ns & & & & & \\
\hline \multicolumn{7}{|c|}{ 6WAT } \\
\hline $\mathrm{RH}$ & 28.6 & 32.4 & 34.6 & 41.1 & 36.3 & 34.6 \\
\hline GS & 30.7 & 34.5 & 35.5 & 38.7 & 41.1 & 36.1 \\
\hline DG & 28.6 & 34.0 & 36.1 & 39.8 & 38.0 & 35.3 \\
\hline MR Mean & 29.3 & 33.6 & 35.4 & 39.9 & 38.5 & \\
\hline LSD (0.05) MM & ns & & & & & \\
\hline MR & 2.80 & & & & & \\
\hline MM x MR & ns & & & & & \\
\hline
\end{tabular}

$\mathrm{RH}=$ Rice Husk, GS=Groundnut Shell, DG=Dry Guinea Grass, MM=Mulch Material, MR=Mulching Rate, NS=Not Significant, $(P \leq 0.05)$, LSD=Least Significant Difference. 
Application of different mulch material had no significant $(P \geq 0.05)$ effect on the plant heights of tomato plants at all the sampling periods (Table 1). The plant heights of tomato was significantly $(\mathrm{P} \leq 0.05)$ influenced by mulching rate at 2 WAT. The plants mulched with 15 tha $^{-1}$ materials was significantly taller than that of 20 tha- 1,5 tha $\urcorner^{-1}$ and control plots but was not significantly different from the plant mulched with 10 tha${ }^{1}(23.9 \mathrm{~cm})$. At 4 WAT, plant height of tomato was significantly $(\mathrm{P} \leq 0.05)$ influenced by mulching rate. The plants mulched with 15 tha $^{-1}(39.9 \mathrm{~cm})$ was significantly taller than other mulching rates while the least mean value $(30.5 \mathrm{~cm})$ was obtained from the control plot which was not significantly different from the plants mulched with 5 tha $^{-1}(31.3 \mathrm{~cm})$.

The plant heights of tomato was significantly $(\mathrm{P} \leq 0.05)$ increased by mulching rate at 6 WAT. The highest mean value $(39.9 \mathrm{~cm})$ was obtained from the plants mulched with 15 tha $^{-1}$ which was not significantly different from the plants mulched with 20 tha $^{-1}(38.5 \mathrm{~cm})$. also, the plants mulched with 10 tha- 1 $(35.4 \mathrm{~cm})$ and 5 tha $1(33.6 \mathrm{~cm})$ were not significantly different

Table 2: Effect of mulch material and mulching rate on number of flowers of tomato plants in 2014 cropping season.

\begin{tabular}{|c|c|c|c|c|c|c|}
\hline \multirow{3}{*}{ Mulch Material } & \multicolumn{6}{|c|}{ Number of Flowers } \\
\hline & \multicolumn{6}{|c|}{ Mulching rate $\left(\right.$ tha $\left.^{-1}\right)$} \\
\hline & 0 & 5 & 10 & 15 & 20 & MM Mean \\
\hline $\mathrm{RH}$ & 15.6 & 18.4 & 21.3 & 28.6 & 24.6 & 21.7 \\
\hline GS & 14.2 & 15.7 & 17.2 & 25.1 & 22.4 & 18.9 \\
\hline DG & 14.3 & 16.6 & 19.7 & 22.5 & 26.1 & 19.8 \\
\hline MR Mean & 14.7 & 16.9 & 19.4 & 25.4 & 24.4 & \\
\hline LSD (0.05) MM & ns & & & & & \\
\hline MR & 4.47 & & & & & \\
\hline MM x MR & ns & & & & & \\
\hline
\end{tabular}

RH=Rice Husk, GS=Groundnut Shell, DG=Dry Guinea Grass, MM=Mulch Material, MR=Mulching Rate, WAT=Weeks After Transplanting, NS=Not Significant, $(P \leq 0.05)$, LSD=Least Significant Difference.

Number of Fruits Per Plant

Table 3: Effect of mulch material and mulching rate on number of fruits per plant of tomato plants in 2014 cropping season.

\begin{tabular}{|c|c|c|c|c|c|c|}
\hline Mulch Material & \multicolumn{5}{|c|}{ Number Of Fruits } \\
\hline & \multicolumn{5}{|c|}{ Mulching Rate (tha ${ }^{-1}$ ) } \\
\hline & 0 & 5 & 10 & 15 & 20 & MM Mean \\
\hline RH & 13.1 & 14.5 & 15.1 & 20.7 & 18.8 & 16.4 \\
\hline GS & 12.6 & 14.3 & 15.1 & 23.7 & 19.8 & 17.1 \\
\hline DG & 10.9 & 13.2 & 13.6 & 19.3 & 17.8 & 15.0 \\
\hline MR Mean & 12.2 & 14.0 & 14.6 & 21.2 & 18.8 & \\
\hline LSD (0.05) MM & $\mathrm{ns}$ & & & & & \\
\hline MR & 3.54 & $\mathrm{n}$ & & & & \\
\hline MM $\times$ MR & $\mathrm{ns}$ & & & & \\
\hline
\end{tabular}

RH=Rice Husk, GS=Groundnut Shell, DG=Dry Guinea Grass, MM=Mulch Material, MR=Mulching Rate, WAT=Weeks After Transplanting, NS=Not Significant, $(P \leq 0.05)$, LSD=Least Significant Difference.

The mean number of tomato fruits is presented in Table 3. The number of fruits increased as the mulching rate increased and declined thereafter. The mulch material had no significant from each other while the least mean value $(29.3 \mathrm{~cm})$ was observed from the un-mulched plants. The interaction effects between mulch material and mulching rate at 2, 4 and 6 WAT were not significant $(\mathrm{P} \geq 0.05)$.

\section{Number of Flowers Per Plant}

The mean number of flowers of tomato is presented in (Table 2). The number of flowers increased as the mulching rate increased and declined thereafter. The mulch material had no significant $(\mathrm{P} \geq 0.05)$ influence on the number of flower of (24.5) and 20 was significantly higher than the plots left un-mulched (control) but significantly had similar number of flowers with the plants mulched with 5 tha $^{-1}$, respectively. The interactive effects of mulch material and mulching rate was not significantly $(\mathrm{P} \geq 0.05)$ influenced. 


\section{Current Trends in Biomedical Engineering \& Biosciences}

of fruits than the control plot (12.2), 5 tha $^{-1}$ (14.0) and 10 tha $^{-1}$ (14.6) but was not significantly different from that of 20 tha $^{-1}$ (18.8). The interaction effects of mulch material and mulching rate was not significantly $(\mathrm{P} \geq 0.05)$ influenced.

\section{Total Fruit Yield}

The total fruit yield of tomato increased as the mulching rate increased and declined thereafter as shown in Table 4 . The total fruit yield of the tomato was no significantly $(\mathrm{P} \geq 0.05)$ increased by mulch material treatments. The total fruit yield of tomato was significantly $(\mathrm{P} \leq 0.05)$ influenced by mulching rate. The plants mulched with 15 tha $^{-1}$ (23.30 tha ${ }^{-1}$ ) was significantly higher than other values of mulching rates. Mulching rate of 20 tha $^{-1}$ (17.57 tha $\mathrm{a}^{-1}$ ) was significantly higher than the plants mulched with 10 tha $^{-1}\left(11.90\right.$ tha $\left.^{-1}\right), 5$ tha $^{-1}\left(10.80\right.$ tha $\left.^{-1}\right)$ and the least was obtained from un-mulched plot $\left(8.13\right.$ tha $\left.^{-1}\right)$. But there was no significant difference between the values of these treatments. The interactive effect of mulch material and mulching rate was not significant $(\mathrm{P} \geq 0.05)$.

Table 4: Effect of mulch material and mulching rate on total fruit yield of tomato plants in 2014 cropping season.

\begin{tabular}{|c|c|c|c|c|c|c|}
\hline \multirow[t]{3}{*}{ Mulch Material } & \multicolumn{6}{|c|}{ Total Fruit Yield (tha ${ }^{-1}$ ) } \\
\hline & \multicolumn{6}{|c|}{ Mulching Rate (tha ${ }^{-1}$ ) } \\
\hline & 0 & 5 & 10 & 15 & 20 & MM Mean \\
\hline $\mathrm{RH}$ & 7.80 & 13.70 & 13.40 & 28.80 & 19.30 & 16.60 \\
\hline GS & 9.30 & 9.20 & 13.40 & 23.20 & 18.60 & 14.70 \\
\hline DG & 7.30 & 9.50 & 8.90 & 17.80 & 14.80 & 11.66 \\
\hline MR Mean & 8.13 & 10.80 & 11.90 & 23.30 & 17.57 & \\
\hline LSD (0.05) MM & ns & & & & & \\
\hline MR & 5.18 & & & & & \\
\hline MM x MR & ns & & & & & \\
\hline
\end{tabular}

RH=Rice Husk, GS=Groundnut Shell, DG=Dry Guinea Grass, MM=Mulch Material, MR=Mulching Rate, WAT=Weeks After Transplanting NS=Not Significant, $(P \leq 0.05), L S D=L e a s t$ Significant Difference.

\section{Crude Protein, Carotene and Iron Contents}

Table 5: Effect of mulch material and mulching rate on protein, carotene and iron content of fruit nutritional qualities of tomato in 2014 cropping season.

\begin{tabular}{|c|c|c|c|c|c|c|}
\hline \multirow[t]{3}{*}{ Mulch Material } & \multicolumn{6}{|c|}{ Nutritional Quality (mg/100 g) } \\
\hline & \multicolumn{6}{|c|}{ Mulching Rate (t ha-1) } \\
\hline & 0 & 5 & 10 & 15 & 20 & MM Mean \\
\hline & \multicolumn{6}{|c|}{ Protein } \\
\hline RH & 0.8 & 1.0 & 0.9 & 1.0 & 1.0 & 0.9 \\
\hline GS & 0.9 & 0.9 & 1.0 & 0.9 & 1.0 & 0.9 \\
\hline DG & 0.8 & 1.0 & 0.9 & 1.0 & 1.0 & 0.9 \\
\hline MR Mean & 0.8 & 1.0 & 0.9 & 1.0 & 1.0 & \\
\hline LSD (0.05) MM & ns & & & & & \\
\hline MR & 0.01 & & & & & \\
\hline MM x MR & ns & & & & & \\
\hline \multicolumn{7}{|c|}{ Carotene } \\
\hline $\mathrm{RH}$ & 0.5 & 0.6 & 0.6 & 0.8 & 0.6 & 0.6 \\
\hline GS & 0.4 & 0.6 & 0.6 & 0.8 & 0.7 & 0.6 \\
\hline DG & 0.4 & 0.6 & 0.7 & 0.7 & 0.7 & 0.6 \\
\hline MR Mean & 0.4 & 0.6 & 0.6 & 0.8 & 0.7 & \\
\hline LSD (0.05) MM & ns & & & & & \\
\hline MR & 0.07 & & & & & \\
\hline MM x MR & ns & & & & & \\
\hline \multicolumn{7}{|c|}{ Iron } \\
\hline $\mathrm{RH}$ & 2.4 & 2.0 & 3.0 & 2.5 & 3.3 & 2.6 \\
\hline GS & 1.6 & 2.3 & 2.2 & 3.6 & 2.6 & 2.5 \\
\hline
\end{tabular}




\section{Current Trends in Biomedical Engineering \& Biosciences}

\begin{tabular}{|c|c|c|c|c|c|c|}
\hline DG & 2.1 & 1.7 & 2.5 & 2.3 & 2.4 & 2.2 \\
\hline MR Mean & 2.0 & 3.0 & 2.6 & 2.8 & 2.8 & \\
\hline LSD (0.05) MM & ns & & & & & \\
\hline MR & 0.22 & & & & & \\
\hline MM x MR & ns & & & & \\
\hline
\end{tabular}

RH=Rice Husk, GS=Groundnut Shell, DG=Dry Guinea Grass, MM=Mulch Material, MR=Mulching Rate, NS=Not Significant, (P $\leq 0.05)$, LSD=Least Significant Difference.

The protein content of tomato fruit was significantly $(\mathrm{P} \leq 0.05)$ influenced by mulching rate (Table 5). Plants mulched with 5,15 and 20 tha $^{-1}(1.0 \mathrm{mg} / 100 \mathrm{~g})$ were significantly higher than that of 10 tha $^{-1}(0.9 \mathrm{mg} / 100 \mathrm{~g})$ and the control plot $(0.8 \mathrm{mg} / 100 \mathrm{~g})$, respectively. The interactive effects of mulch material and mulching rate was not significant $(\mathrm{P} \geq 0.05)$ on protein content.

Mulching rate had significant $(\mathrm{P} \leq 0.05)$ influence on carotene content of tomato fruit with the highest mean value $(0.8 \mathrm{mg} / 100 \mathrm{~g})$ obtained with 15 tha $^{-1}$ which was significantly higher than other mulching rates. The plants mulched with 20 tha- $1(0.7 \mathrm{mg} / 100 \mathrm{~g})$ was significantly higher than that of 5 tha $^{-1}$ and $10 \mathrm{tha}^{-1}(0.6 \mathrm{mg} / 100 \mathrm{~g})$ which had no significant difference

from each other while the least carotene content $0.4 \mathrm{mg} / 100 \mathrm{~g}$ was received from un-mulched plot. The interactive effect of mulch material and mulching rate was not significant $(\mathrm{P} \geq 0.05)$.

The result showed that iron content of tomato fruit was significantly $(\mathrm{P} \leq 0.05)$ influenced by mulching rate. The highest mean value $(3.0 \mathrm{mg} / 100 \mathrm{~g})$ was obtained with 5 tha $^{-1}$ which was significantly higher than the plants mulched with 10 tha $^{-1}$ $(2.6 \mathrm{mg} / 100 \mathrm{~g})$ and the control plot $(2.0 \mathrm{mg} / 100 \mathrm{~g})$ but significantly recorded similar iron content with the plants mulched with 15 tha ${ }^{-1}$ and 20 tha $^{-1}(2.8 \mathrm{mg} / 100 \mathrm{~g})$. The interaction effects of mulch material and mulching rate on iron content of tomato fruit was not significant $(\mathrm{P} \leq 0.05)$.

\section{Phosphorus, Potassium and Calcium contents}

Table 6: Effect of mulch material and mulching rate on phosphorus, potassium and calcium fruit nutritional qualities of tomato plants in 2014 cropping season.

\begin{tabular}{|c|c|c|c|c|c|c|}
\hline \multirow{3}{*}{ Mulch Material } & \multicolumn{6}{|c|}{ Nutritional Quality (mg/100g) } \\
\hline & \multicolumn{6}{|c|}{ Mulching Rate (tha-1) } \\
\hline & 0 & 5 & 10 & 15 & 20 & MM Mean \\
\hline \multicolumn{7}{|l|}{ Phosphorus } \\
\hline $\mathrm{RH}$ & 2.9 & 3.4 & 4.2 & 4.9 & 6.5 & 4.4 \\
\hline GS & 3.5 & 4.1 & 5.3 & 5.8 & 6.3 & 5.0 \\
\hline DG & 5.1 & 6.4 & 6.2 & 7.9 & 7.6 & 6.6 \\
\hline MR Mean & 3.8 & 4.6 & 5.2 & 6.2 & 6.8 & \\
\hline LSD (0.05) MM & 0.36 & & & & & \\
\hline MR & 0.36 & & & & & \\
\hline $\mathrm{MM} \times \mathrm{MR}$ & 0.13 & & & & & \\
\hline \multicolumn{7}{|l|}{ Potassium } \\
\hline RH & 2.4 & 3.8 & 4.0 & 4.6 & 4.5 & 3.9 \\
\hline GS & 2.8 & 2.7 & 3.4 & 4.3 & 5.2 & 3.7 \\
\hline DG & 2.4 & 2.9 & 3.3 & 5.5 & 5.1 & 3.8 \\
\hline MR Mean & 2.5 & 3.1 & 3.6 & 4.8 & 4.9 & \\
\hline LSD (0.05) MM & ns & & & & & \\
\hline MR & 0.26 & & & & & \\
\hline $\mathrm{MM} \times \mathrm{MR}$ & ns & & & & & \\
\hline \multicolumn{7}{|l|}{ Calcium } \\
\hline RH & 1.8 & 2.0 & 2.5 & 2.9 & 2.7 & 2.4 \\
\hline GS & 1.3 & 1.5 & 2.2 & 2.4 & 3.0 & 2.1 \\
\hline DG & 1.5 & 2.0 & 2.0 & 2.9 & 2.8 & 2.2 \\
\hline MR Mean & 1.5 & 1.8 & 2.2 & 2.7 & 2.8 & \\
\hline
\end{tabular}




\begin{tabular}{|c|l|l|l|l|l|l|}
\hline LSD (0.05) MM & 0.18 & & & & \\
\hline MR & 0.18 & & & & & \\
\hline MM X MR & 0.03 & & & & & \\
\hline
\end{tabular}

Mulch material had significant $(\mathrm{P} \leq 0.05)$ influence on phosphorus content of tomato fruit (Table 6). The dry guinea grass mulch recorded the highest mean value $(6.6 \mathrm{mg} / 100 \mathrm{~g})$ which was significantly higher than the mean value $(5.0 \mathrm{mg} / 100 \mathrm{~g})$ obtained from the groundnut shell mulch and the least mean value $(4.4 \mathrm{mg} / 100 \mathrm{~g})$ was received from rice husk mulch. Mulching rate had significant $(\mathrm{P} \leq 0.05)$ effect on phosphorus content of tomato fruit. The highest mean value $(6.8 \mathrm{mg} / 100 \mathrm{~g})$ was obtained from the plants mulched with 20 tha $^{-1}$ which was significantly higher than the mulching rates of 5 tha $^{-1}$ and 10 tha $^{-1}$. But had no significant difference from that of 15 tha $^{-1}(6.2 \mathrm{mg} / 100 \mathrm{~g})$ while the least mean value $(3.8 \mathrm{mg} / 100 \mathrm{~g})$ was observed from unmulched plot. The interaction of mulch material and mulching rate was significant $(\mathrm{P} \leq 0.05)$ on phosphorus content with the highest mean value $(7.9 \mathrm{mg} / 100 \mathrm{~g})$ obtained from dry guinea grass mulch at 15 tha $^{-1}$.

The potassium content of tomato fruit was not significantly $(\mathrm{P} \geq 0.05)$ affected by mulch material. Mulching rate had significant $(\mathrm{P} \leq 0.05)$ influence on potassium content of tomato fruit. The plants mulched with 20 tha $^{-1}(4.9 \mathrm{mg} / 100 \mathrm{~g})$ was Lycopene, Magnesium and Vitamin C Contents

Table 7: Effect of mulch material and mulching rate on lycopene, magnesium and vitamin $\mathrm{C}$ fruit nutritional qualities of tomato plants in 2014 cropping season.

\begin{tabular}{|c|c|c|c|c|c|c|}
\hline \multirow{3}{*}{ Mulch Material } & \multicolumn{6}{|c|}{ Nutritional Quality (mg/100g) } \\
\hline & \multicolumn{6}{|c|}{ Mulching Rate (tha-1) } \\
\hline & 0 & 5 & 10 & 15 & 20 & MM Mean \\
\hline \multicolumn{7}{|c|}{ Lycopene } \\
\hline RH & 1.9 & 2.7 & 2.9 & 3.5 & 3.7 & 2.9 \\
\hline GS & 1.5 & 1.7 & 2.3 & 2.8 & 3.0 & 2.3 \\
\hline DG & 1.5 & 2.5 & 2.6 & 3.5 & 4.1 & 2.8 \\
\hline MR Mean & 1.6 & 2.3 & 2.6 & 3.3 & 3.6 & \\
\hline LSD (0.05) MM & 0.16 & & & & & \\
\hline MR & 0.16 & & & & & \\
\hline $\mathrm{MM} \times \mathrm{MR}$ & ns & & & & & \\
\hline \multicolumn{7}{|c|}{ Magnesium } \\
\hline $\mathrm{RH}$ & 11.1 & 8.6 & 12.9 & 11.7 & 15.3 & 11.9 \\
\hline GS & 7.1 & 12.5 & 9.4 & 16.2 & 9.5 & 10.9 \\
\hline DG & 11.1 & 8.4 & 12.9 & 9.9 & 8.8 & 10.2 \\
\hline MR Mean & 9.8 & 9.8 & 11.7 & 12.6 & 11.2 & \\
\hline LSD (0.05) MM & ns & & & & & \\
\hline MR & ns & & & & & \\
\hline MM x MR & ns & & & & & \\
\hline \multicolumn{7}{|c|}{ Vitamin C } \\
\hline $\mathrm{RH}$ & 16.1 & 20.2 & 17.8 & 28.3 & 25.3 & 21.5 \\
\hline
\end{tabular}




\section{Current Trends in Biomedical Engineering \& Biosciences}

\begin{tabular}{|c|c|c|c|c|c|c|}
\hline GS & 16.5 & 16.7 & 23.8 & 21.3 & 28.7 & 21.4 \\
\hline DG & 15.0 & 19.9 & 16.8 & 22.9 & 23.6 & 25.9 \\
\hline MR Mean & 15.9 & 18.9 & 19.5 & 24.2 & & \\
\hline LSD (0.05) MM & ns & & & & & \\
\hline MR & 2.22 & & & & & \\
\hline MM x MR & ns & & & & \\
\hline
\end{tabular}

RH=Rice Husk, GS=Groundnut Shell, DG=Dry Guinea Grass, MM=Mulch Material, MR=Mulching Rate, NS=Not Significant, (P $\leq 0.05)$, LSD=Least Significant Difference.

The mulch material had significant $(\mathrm{P} \leq 0.05)$ influence on lycopene content of tomato fruit (Table 7). The plants treated with rice husk mulch recorded the highest mean value $(2.9 \mathrm{mg} / 100 \mathrm{~g})$ which was significantly higher than the plants treated with groundnut shell mulch $(2.3 \mathrm{mg} / 100 \mathrm{~g})$ but was not significantly different from the plots applied with dry guinea grass mulch $(2.8 \mathrm{mg} / 100 \mathrm{~g})$. The lycopene content of tomato fruit was significantly $(\mathrm{P} \leq 0.05)$ increased by mulching rate. The plants mulched with 20 tha $^{-1}(3.6 \mathrm{mg} / 100 \mathrm{~g})$ was significantly higher than other mulching rates. Also, plants mulched with 15 tha- 1 $(3.3 \mathrm{mg} / 100 \mathrm{~g})$ was higher than that of 10 tha $^{-1}(2.6 \mathrm{mg} / 100 \mathrm{~g})$ and 5 tha $^{-1}(2.3 \mathrm{mg} / 100 \mathrm{~g})$ while the least mean value $(1.6 \mathrm{mg} / 100 \mathrm{~g})$ was obtained from un-mulched plot. The interactive effect of mulch material and mulching rate on lycopene content was not significant $(\mathrm{P} \geq 0.05)$.

Magnesium content of tomato fruit was not significantly $(P \geq 0.05)$ influenced by mulch material, mulching rate and their interaction effects. The vitamin $\mathrm{C}$ content of tomato fruit was not significantly $(\mathrm{P} \geq 0.05)$ influenced by application of mulch material. The vitamin $\mathrm{C}$ content of tomato fruit was significantly $(\mathrm{P} \leq 0.05)$ influenced by mulching rate. Plants mulched with 20 tha $^{-1}(25.9 \mathrm{mg} / 100 \mathrm{~g})$ was significantly higher than that of 10 tha $^{-1}(19.5 \mathrm{mg} / 100 \mathrm{~g})$ and 5 tha $^{-1}(18.9 \mathrm{mg} / 100 \mathrm{~g})$. But was not significantly different from 15 tha $^{-1}(24.2 \mathrm{mg} / 100 \mathrm{~g})$ while the least mean value $(15.9 \mathrm{mg} / 100 \mathrm{~g})$ was obtained from the control plot. The interaction of mulch material and mulching rate on vitamin $C$ content had no significant $(P \geq 0.05)$ effect.

\section{Discussion}

Reports by Liasu and Abdul Kabir [8] stated that mulching is a layer of material on the surface of the soil used to keep soil moist or to serve a wide variety of purposes. Organic mulches are those derived from the dead plant and animal tissues, which apart from soil protection also serve as nutrient sources when they decay. Findings from [19] revealed that mulching tomato plants with the use of water hyacinth, straw, am-ada leaf and banana leaf showed significant effect on growth and yield components and thus increase the yield. The significant plant height of $39.9 \mathrm{~cm}$ obtained with the mulching rate of 15 tha $^{-1}$ from the present study agrees with the report of Liasu and Abdul Kabir [8] who stated that tomato plants subjected to mulching exhibited the highest plant height when compared with control.
The above authors in their findings also stated that the tomato plants subjected to mulching exhibited the highest number of leaves per plant than the control plot.

In the current study, mulching rate of 15 tha $^{-1}$ and 20 tha ${ }^{1}$ produced number of flowers of 25.4 and 24.4 that were significantly higher than the values of other mulching rates. This may be attributed to the fact that the mulching application rate was higher thereby retaining moisture in the soil which promoted flower formation. This is in agreement with Anon [5] who reported that the thicker the mulch material the more water is retained in the soil to serve as a good medium for plant growth, development and efficient crop production. The results obtained from this study revealed that rice husk mulch gave higher number of fruits than other mulch materials. This agrees with the report of Akhtar et al. [6] who reported that natural mulches such as leaf, rice straw, dead leaves and compost have been used for centuries to increase fruit per plant, fruit length, fruit size, average fruit weight and yield. Findings in this study also agrees with those of Kayum et al. [9] who stated that mulching showed significant effect on growth, yield components and thus on the yield of tomato.

The significant highest total fruit yield of 23.30 tha $^{-1}$ produced from the plants mulched with 15 tha- 1 in this study was at the upper value of 14.00 tha- 1 reported by Gudugi et al. [14] and 21.47 tha $^{-1}$ reported by Elkner et al. [24]. The results of the current study is in conformity with Ertek et al. [16] who revealed that mulching tomato plants at the rate of 10 to 20 tha- 1 will give better yield using mulch materials such as green leaves, dried leaves and coconut fronds. The significant increase in the fruit nutritional qualities parameters which mulch materials and mulching rates treatments were imposed showed the potentials involved in tomato variety. The nutritional composition increased as the mulching rates increased. The result obtained from this present study is in agreement with the findings of Olaniyi et al. [25]. There was no consistency in the nutritional qualities obtained in this current study for the tomato variety used. The plants mulched with 15 tha $^{-1}$ closely followed by 20 tha-1 significantly recorded higher nutritional qualities than the other mulching rates evaluated. The result of this study is in line with the findings of Olaniyi et al. [25] who confirmed that there was inconsistence in the nutritional values obtained in their study for the tomato varieties used. Ara et al. [26] supported 
the result obtained in this study that tomato is a dependable source of Vitamin A, B, C and D, minerals, Ca, P and Fe. Result of the nutritional qualities revealed that tomato fruits are rich in phosphorus, potassium, calcium and vitamin C. This might be the reason of their intensive use for stew in meals.

\section{Conclusion}

Based on the research findings, it can be concluded that Rice husk mulch gave better fruit yield and nutritional qualities than groundnut shell and dry guinea grass mulches. More so, the plants mulched with 15 tha $^{-1}$ gave the highest fruit yield and nutritional qualities than other treatments. It is therefore recommended for the tomato farmers within the study areas.

\section{References}

1. Zeidan 0 (2005) Tomato production under protected condition. Ministry of Agriculture and Rural Development. The center for International Agriculture Development Cooperation pp. 43-44.

2. Villareal RL (1980) Tomato in the tropics. West view Press Boulder, Colorado p. 174.

3. Omar Z (2005) Tomato production under protected conditions Published by Mashav, Cinad co and the peres center for peace project coordinator pp. 71-112.

4. Balarabe S (2012) Tomato production in Nigeria: issues and prospects. Ministry of Agriculture and Rural Development Kano, Kano State.

5. Anon (2009) National Horticultural Research Institute. Annual Report for vegetable production.

6. Akhtar S, Wahid A, Akram M, Rausl E (2001) Some growth, photosynthetic and anatomical attributes of sugarcane genotypes under $\mathrm{NaCl}$ salinity. International Journal of Agriculture and Biology 3(4): 439-443.

7. Enan SA (2004) Effect of transplanting and soil application of boron and zinc on yield and quality of sugar beet. Ph.D. Thesis Al-Azhar University of Egypt pp. 150-152.

8. Liasu MO, kabir KAA (2007) Influence of Lithonia divers folia leaf mulch and Fertilizer Application on the Growth and Yield of Potted Tomato Plants. American-Eurasian J. Agric. \& Environ. Sci 2 (4): 335340.

9. Kayum MA, Asaduzzaman M, Haque MZ (2008) Effect of indigenous mulches on growth and yield of tomato. Journal of Agriculture and Rural Development 6(1-2): 1-6.

10. Hooda RS, Singh J, Malik YS, Batra VK (1999) Influence of direct seedling, transplanting time and mulching on tomato yield. Vegetable Science 26(2): 140-142.
11. Bhagat RM, Acharya CL (1988) Soil water dynamics during wheat growth under different management practices. J Indian Soc Soil Sci 36: 389-396.

12. Walter B, (1988) Influence of bark mulch on water balance, soil water quality, mineralization and nitrification in skeletal Devonian viney and soils. Horticulture 59(9): 835.

13. George A (2004) Horticuture principles and practices. Published by Asoke K Pp. 709-710.

14. Gudugi IAS, Odofin AJ, Adeboye MKA, Oladiran JA (2012) Agronomic characteristics of tomato as influenced by irrigation and mulching. Advances in Applied Science Research 3(5): 2539-2543.

15. Agbo, R.S.K. (2000) The effects of L. leucocephala and G. Sepium mulches and their mixtures on the growth and yield of okra. Master of Science Degree Thesis, Kwame Nkrumah University of Science and Technology, Kumasi pp. 44-45.

16. Ertek A, Sensoy S, Kuecuekyumuk C, Gedik I (2004) Agricultural water management 67: 63-76.

17. Norman QA, Clive AE (2005) Effects of vermicompost on plant growth. Paper presented during the International Symposium workshop on vermi Technologies for Developing Countries, Los Banos, Philippines 16-18.

18. FAO (1999) Soil fertility initiation for Sub-Saharan Africa. World Soil Resource Reports 85:82.

19. Wood AW (1991) Management of crop residues following green harvesting of sugarcane in north Queensland. Soil and Tillage Research 20: 69-85.

20. Linedale A, Bull B (1995) Onfarm popular at Bundaberg. Sugar Agronomy 2: pp. 29.

21. Schlesselma JJ, Ritenour GL, Hile MMS (1985) Cultural Control Methods Principles of Weed Control in California. Thompson publications. pp. 35-49.

22. Acayen, Magdaraog, Matriano, L.G. Rivero et al. (2004) Dried papaya leaves as organic mulch for tomato plants. Bato Balani for science and Technology 24: 1 .

23. IITA (1989). Automated and semi-automated methods for soil and plant analysis. Manual series No. 7. IITA, Ibadan, Nigeria.

24. Elkner K, Kaniszewski S, Gerasopoulos D, Passam H (1991) Effect of drip irrigation and mulching on quality of tomato fruits. Acta Horticulturae, 379: 175-180.

25. Olaniyi JO, Akanbi WB, Adejumo T A, Akande OG (2010) Growth, fruit yield and nutritional quality of tomato varieties. African Journal of Food Science 4(6): 398-402.

26. Ara N, Bashar MK, Begun S, Kakon SS (2007) Effect of spacing and stem pruning on the growth and yield of tomato. Int. J. Sustain. Crop Prod 2(3): 35-39.

This work is licensed under Creative

Commons Attribution 4.0 License

DOI: $10.19080 /$ CTBEB.2017.05.555663
Your next submission with Juniper Publishers will reach you the below assets

- Quality Editorial service

- Swift Peer Review

- Reprints availability

- E-prints Service

- Manuscript Podcast for convenient understanding

- Global attainment for your research

- Manuscript accessibility in different formats (Pdf, E-pub, Full Text, Audio)

- Unceasing customer service

Track the below URL for one-step submission https://juniperpublishers.com/online-submission.php 